\title{
Storm and Calm
}

Author(s): Nominis Umbra

Source: All Ireland Review, Vol. 2, No. 37 (Nov. 16, 1901), p. 290

Published by: All Ireland Review

Stable URL: http://www.jstor.org/stable/20545653

Accessed: 22-06-2016 00:06 UTC

Your use of the JSTOR archive indicates your acceptance of the Terms \& Conditions of Use, available at

http://about.jstor.org/terms

JSTOR is a not-for-profit service that helps scholars, researchers, and students discover, use, and build upon a wide range of content in a trusted

digital archive. We use information technology and tools to increase productivity and facilitate new forms of scholarship. For more information about JSTOR, please contact support@jstor.org.

All Ireland Review is collaborating with JSTOR to digitize, preserve and extend access to All Ireland Review 
fore, not surprising that in such a country, and amongst such a people, the hound should have been the type of heroism. The Irish demi-gods were not only compared to hounds, but actually bores names in which the Gaelic word for hound appears in composition -for example, Cu-Culain, the hound of Culain; Con-aill, Noble Hound; ConCobar, Hound of Succour. Con is only $\mathrm{cu}$ in one of the oblique cases. A people who called their demi-gods hounds were surely accustomed to a race of dogs of a very great and majestic character. Hisrokicus.

\section{STORM AND CALM}

TO THE EDITOR ALL IRELAND REVIEW.

Dear Sir,_- "Cast thy bread upon the waters" says the Scripture, "and thou shalt find it after many days." Mr. Rolleston's communication in your last number was so curious to one of the more obscure subscribers to the A. I. R., whose name is not known to your readers, that he cannot allow it to pass without notice. Fifteen years ago, as a schoolboy, the present writer was in the habit of composing verses and enclosing them in envelopes directed to such prominent magazines as the "Nineteenth Century," "Longman's," etc., and in one of these poems he began to recognise as he glanced over this piece of pretentious nonsense, certain pinece which had appeared at first strangely familiar to him. Well, it has dispelled a pleasing illusion which he had that he wrote rhyme plus reason at so early an age. It may in terest Mr. Rolleston to learn that the writer has grown into an individual with few acknowledged characteristics of the poetic temperament, sober, industrious, and high-principled, and whe, so far from "looking on fine phrases like a lover,' as Keats says, has acquired a complete distaste for all writing: which is not an absolute skin fit to the thought which it clothes Nor, bearing in mind what Plato says of the man who "approaches the gates of poetry without madness," can he honestly accept with complacence your description of him as " cracked," either at the time these verses were composed or now. At least, that is not an impu tation, under the protecting cloak of which he has hitherto been allowed to pursue, as it pleased him, his journey pursue, as it pleased him, his journey Mr. Rolleston, who has perhaps thought it possible that someone who had acquired a certain degree of literary reputation would come forward, who putation would come forward, who
could affiord smilingiy to acknowledge this youthful indiscretion. I cannot justify his judgment, nor, honestly can I see what he saw in these verses which made him lay them aside.

Let me take this opportunity to express the goodwill which I bear the A. I. R., whose determination to exclude the weighty review manner, and to cull fragments of opinion from all sorts and conditions of people, strikes me as an excellent idea. Perhaps such a paper the present condition of intellectual affairs in Ireland. Yet, I think a paper is wanted in which a writer can have his say rather more freely than in the few paragraphs of a letter, or of those despicably unobjectionable articles which bear the imprimatur of archbishops.-Yours truly,

Nominis Umbra.
WELL, CONSIDERED ARTICLES.

DEAR A.I.R.-I am so glad that you have put your foot down upon those "Well considered articles." They are in the main dreadful things. We have been deluged with them for time out of mind: and what good have they done us? We have been stormed at; and shrieked at; prayed over; wept over; cursed and blessed in "well considered articles" as long as I can remember; with the nett result that they have become our abomination.

I have not read a "well considered article" for goodness knows how long; and most people I come across are of the same temper.

What on earth do we want with "well considered articles"? Youwho change your coat with the seasons and take holidays like a sensible man and stop ; and go on; with a noble disdain of such things as circulation and subscribers! "Well considered articles" indeed! Your article would not suit them. And only think of their effect on your inside! Why they would be absolutely foreign matter. I tremble to imagine their result on your constitution.

You are delightful while you are simple, natural, an expression of the kindly mind we read in you. And I read you with real pleasure while you are kindly and unconventional; and while there is no breath of the "well considered article" about you.

No ! dear A.I.R. Remain a butterfly. Flit about in the sun; and lead us from flower to flower; from rath to dun; from fairy ring to weird ruin. Show us the lovely things of this sweet land of ours, and we will follow you like little children. And we will gather charity and philosophy as we go. You will agree that the greatest of all virtues is but a certain quantity in these "well considered articles"; and further, that there is more of wit and wisdom in one of our Irish fairy tales than is banged out of the war drums, and hooted out of the foghorns, of all our mighty controversialists in twelve months.

So please dear A.I.R. keep clear of those "well considered articles," and remain as you are.

We are so much indebted to A.E. for that fascinating glimpse of the story of Deirdre. What a beautiful story it is ? And how full of infinite pathos! And yet there are creatures who say that reland has no literature !

I do hope that A.E. does not mean to stop. Do ask A.E. to go on; and add our prayers to your own. And as the story continues let us have Concobar painted in his true colours. I have al ways hated that King. He was a brute. Louis XI. of France was a Paladin beside him. And let Deirdre die by the grave of the sons of Usnach.

P.S.-What are you doing the third week in December. You know you have promised to come to see us here.Sincerely yours,

\section{T. Grattan Esmonde.}

[Dear Sir Gratran Esmonde-Thanks for you pleasant and sensible letter. My hostility to the well-considered article, as you rightly suspect, is not a whim but a deliberate opinion founded on experience. When the Financial Relations question was up, and when there was a chance that we might unite over it, and so go, as it were, into action. I wrote some one hundred and fifty well considered articles upon the subject for the edification of my own County, approacing thoseabominable relations from every conceivable or imaginable point of view, sustained as I was by the thought that if I could get one County to stir, it would stir the rest. Then I stopped, and, like Wordsworth's skater, though not so pleased as he, listened to the fading echoes of my own voice. Like twenty-five other Counties we too formed a County Committee, and the County Committee would not stir for all my shouting. Like the rest of the twenty-five, my County Committe would not even sit! High and low we are all the same, all under the Spell.

In this country the well considered article is really not well considered at all, for it is without purpose and intention. It resembles that fine boat which Robinson Crusoe spent years in building and which he was not able to launch, and which he knew, while making it, that he never could launch.

However, I mustn't lose my temper over it, for I suppose we are and shall remain as God made us-or Wolfe Tone, for I do believe that all the mischief began with Tone, Tone and his revolutionary Belfast friends, in their eagerness to attain their objective by a short cut. They failed rather miserably, but succeeded in splitting Ireland into hostile camps and paralyzing the national will ever since.

Thanks for invitation, which I accept with pleasure; only you must let me do as I please, if I like, strolling all day in your woods. I think I like woods best in winter, and think you are w rong about Concobar.-ED. A.I.R.]

\section{"A MATTER FOR SOLICITURS."}

TO THE EDITOR OF THE ALL IRELAND REVIEW.

DEAR SIR.-As a solicitor's conducting clerk $I$ was very much interested in your article (headed as above), and write to ask if you have ever known the solicitors themselves to demand and pocket the "usual commission," perhaps because they did not wish their clerk to resort to such " furtive unmanly ways of making money." At all events, I am in the employment of a firm that does so. I enclose card, but not for publi. cation.

Caman.

[Solicitors indulging in such practices ought to be struck from the rolls. Such, however, are I am sure very few.

I would thank all Editors of rural newspaners when they $r$ ceive applications for that ten per cent., the chief cl:rks' black mail, to let me know. They need not fear that I shall disclose their names._ED. A.I.R.] 